\title{
Historical impact of water infrastructure on water levels of the Mekong River and the Tonle Sap system
}

\author{
T. A. Cochrane ${ }^{1}$, M. E. Arias ${ }^{1,3}$, and T. Piman ${ }^{2}$ \\ ${ }^{1}$ Dept. of Civil and Natural Resources Engineering, University of Canterbury, Christchurch, New Zealand \\ ${ }^{2}$ Climate Change and Adaptation Initiative, Mekong River Commission, Vientiane, Lao PDR \\ ${ }^{3}$ Sustainability Science Program, Harvard University, Cambridge, USA \\ Correspondence to: T. A. Cochrane (tom.cochrane@ canterbury.ac.nz)
}

Received: 7 March 2014 - Published in Hydrol. Earth Syst. Sci. Discuss.: 24 April

Revised: 29 September 2014 - Accepted: 29 September 2014 - Published: 17 November 2014

\begin{abstract}
The rapid rate of water infrastructure development in the Mekong Basin is a cause for concern due to its potential impact on fisheries and downstream natural ecosystems. In this paper, we analyze the historical water levels of the Mekong River and Tonle Sap system by comparing pre- and post-1991 daily observations from six stations along the Mekong mainstream from Chiang Saen (northern Thailand), to Stung Treng (Cambodia), and the Prek Kdam station on the Tonle Sap River. Observed alterations in water level patterns along the Mekong are linked to temporal and spatial trends in water infrastructure development from 1960 to 2010 . We argue that variations in historical climatic factors are important, but they are not the main cause of observed changes in key hydrological indicators related to ecosystem productivity. Our analysis shows that the development of mainstream dams in the upper Mekong Basin in the post-1991 period may have resulted in a modest increase of 30-day minimum levels $(+17 \%)$, but significant increases in fall rates $(+42 \%)$ and the number of water level fluctuations $(+75 \%)$ observed in Chiang Saen. This effect diminishes downstream until it becomes negligible at Mukdahan (northeast Thailand), which represents a drainage area of over $50 \%$ of the total Mekong Basin. Further downstream at Pakse (southern Laos), alterations to the number of fluctuations and rise rate became strongly significant after 1991. The observed alterations slowly decrease downstream, but modified rise rates, fall rates, and dry season water levels were still quantifiable and significant as far as Prek Kdam. This paper provides the first set of evidence of hydrological alterations in the Mekong beyond the Chinese dam cascade in the upper Mekong. Given the evident alterations at Pakse
\end{abstract}

and downstream, post-1991 changes could also be directly attributed to water infrastructure development in the Chi and Mun basins of Thailand. A reduction of 23 and $11 \%$ in the water raising and falling rates respectively at Prek Kdam provides evidence of a diminished Tonle Sap flood pulse in the post-1991 period. Given the observed water level alterations from 1991 to 2010 as a result of water infrastructure development, we can extrapolate that future development in the mainstream and the key transboundary Srepok, Sesan, and Sekong sub-basins will have an even greater effect on the Tonle Sap flood regime, the lower Mekong floodplain, and the delta.

\section{Introduction}

The Mekong River is one of the world's great rivers, originating in the Tibetan highlands and draining into the South China Sea where it forms the Vietnam delta. It has a length of over $4180 \mathrm{~km}$, drains an area of $795000 \mathrm{~km}^{2}$, and has a mean annual discharge flow of $14500 \mathrm{~m}^{3} \mathrm{~s}^{-1}$ (MRC, 2005). The Mekong's hydrology is driven by the Southeast Asian monsoons, causing the river to have a distinct seasonal flood pulse. A unique feature of the Mekong River is its interaction with Southeast Asia's largest lake, the Tonle Sap in Cambodia. The Mekong River receives discharge water from Tonle Sap during the dry season (November to May) via the Tonle Sap River; during the wet season (June to October), the floodwaters of the Mekong reverse the direction of the Tonle Sap River and flow into the lake, causing its surface area to expand from $2600 \mathrm{~km}^{2}$ to approximately $15000 \mathrm{~km}^{2}$. 
The Tonle Sap system, along with the Mekong River and its tributaries, are also considered one of the world's most productive freshwater fisheries (Baran and Myschowoda, 2009). Fish catch in the Mekong and Tonle Sap provides over 50\% of the protein consumed by humans in the lower Mekong (Hortle, 2007). The natural seasonal flood pulse and hydrological water level patterns of the Mekong are attributed as being principal features for maintaining the system's high ecosystem productivity (Holtgrieve et al., 2013).

While the boom for hydropower development peaked in the 1970s around the world (WCD, 2000), civil conflict and political instability maintained the Mekong Basin untapped for several decades. The lower Mekong has been recently described as an unregulated river near natural conditions (Kummu et al., 2010; Grumbine and Xu, 2011; Piman et al., 2013a) and global assessments show that the Mekong has low to moderate levels of fragmentation and regulation comparable to large rivers such as the Amazon and Congo (Nilsson et al., 2005; Lehner et al., 2011). This general perception of a pristine Mekong has been rapidly changing as water infrastructure projects have materialized throughout the basin in recent years. Much attention has been focused on mainstream dams in China and proposed dams and those under construction in Laos. There are, however, a large number of dams in the Mekong tributaries that have been built since the early 1990s with undocumented hydrological alterations and environmental impacts. Furthermore, there are over a hundred dams being proposed for development throughout the basin, most of which are planned in the tributaries (MRC, 2014); thus, quantifying and understanding the level of hydrological alterations from historical development is critical information for improving predictions for the upcoming decades in the Mekong.

Evidence of how dams and irrigation affect natural river regimes has been widely documented throughout the world (Nilsson et al., 2005; Lehner et al., 2011). Dam operations, for example, can affect rivers by redistributing and homogenizing flows, which is reflected in decreased seasonal and interannual variability (Poff et al., 2007). These temporal trends, however, can also be affected by other factors such as climate, making the distinction between dam-driven vs. climate-driven alterations troublesome at times. To overcome this issue, it is necessary to identify specific hydrological parameters that are solely associated with water infrastructure development.

Ritcher et al. (1996) proposed the use of 32 hydrological parameters as indicators of hydrological alteration. These indicators are broadly grouped into five classes: (1) mean monthly values, (2) magnitude and duration of extreme water conditions, (3) timing of extreme water conditions, (4) frequency and duration of high/low pulses, and (5) rate and frequency of water condition changes (Ritcher et al., 1996). Even though some indicators in the first two classes have also been used to assess alterations associated with climate change (e.g., Döll and Zhang, 2010), the cumulative alteration of multiple classes has been primarily associated with river regulation by dams (Poff et al., 1997; Ritcher et al., 1997; Gao et al., 2009).

Localized evidence of dam-related hydrological alterations has been documented in the Mekong, but it is generally accepted that system-wide disruptions are not yet readily evident (Adamson et al., 2009). For the Yali Falls dam in the Sesan River in Vietnam, significant downstream water level fluctuations and increases in dry season water levels have been directly attributed to the operation of the dam, which have caused adverse ecological and social impacts including bank erosion, adverse effects on sandbar-nesting birds, disruptions to fishing, shellfish collection, and others (Wyatt and Baird, 2007). A number of studies have analyzed the localized impact of the Lancang Jiang hydropower cascade in the upper Mekong in China. For instance, $\mathrm{Li}$ and $\mathrm{He}$ (2008) studied linear trends in multiyear mean water levels and concluded that no major alterations occurred as a result of the first two dams in China's cascade. On the other hand, Lu and Siew (2006) found a significant decrease in dry season water levels and an increase in water level fluctuations in 1993-2000 at Chiang Saen, immediately downstream from the Chinese dam cascade. More recently, Lu et al. (2014) assessed alterations to monthly water discharge at that same station up until 2010 and found moderate alterations during March and April. The effect of the Chinese dams has also been investigated through modeling studies by Räsänen et al. (2013) and Piman et al. (2013a), who reported potential increases in dry season water discharge as far downstream as Kratie in central Cambodia. To the best of our knowledge, no study has documented hydrological alterations in the Mekong caused by dams or other water infrastructure beyond the Chinese dam cascade.

Contemporary basin-wide hydrological shifts have been documented in the Mekong, but they have been primarily attributed to climatic patterns and not water infrastructure development. In particular, a strong link between the El Niño-Southern Oscillation (ENSO) and inter-decadal patterns in wet season precipitation and river discharge of the Mekong has been suggested (Delgado et al., 2012; Räsänen and Kummu, 2013). As 80-90\% of the Mekong's discharge occurs from May to October (Delgado et al., 2012), most of the research linking climate and river discharge has focused on the distinct wet season months (typically June to October). In general, strong El Niño periods have corresponded to years of lower-than-normal wet season floods in the Mekong, whereas La Niña periods have corresponded to years of higher than normal floods. The strong shift in the North Pacific was also detectable in the lower Mekong wet season discharge (Delgado et al., 2012), and overall, interannual variability in flood levels have significantly increased during the 20th century (Delgado et al., 2010; Räsänen et al., 2013). With regards to the dry season, Cook et al. (2012) studied the relationships between lower Mekong water discharge during March-May with snow cover and local precipitation. With 


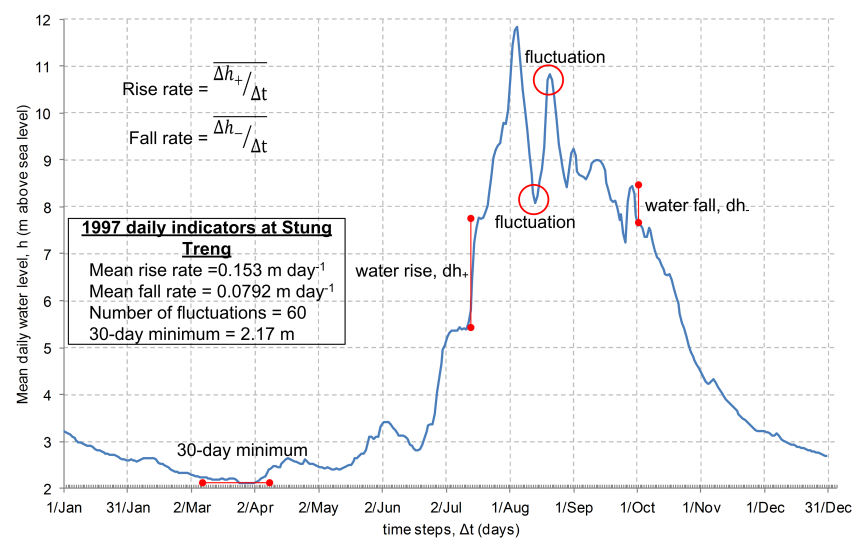

Figure 1. Illustration of hydrological alteration indicators most sensitive to reservoir operations. Hydrograph represents mean daily water levels during 1997 at Stung Treng.

opposite trends in snow cover (decrease) and precipitation (increase), Cook et al. (2012) estimated negligible effects of these two factors in the lower Mekong discharge during contemporary decades. How climate-driven shifts have interacted with historical water infrastructure development has not been studied, although modeling studies of the future Mekong indicate that dam-driven alterations could be more noticeable and less uncertain than climate change alterations (Lauri et al., 2012).

The purpose of this study is to quantify and reveal observed alterations to water levels along the Mekong River and Tonle Sap system and determine their link to spatial and temporal patterns of water infrastructure development in the basin. We analyzed historical records of daily water levels in seven stations along the Mekong and Tonle Sap and compute indicators of hydrological alterations that have been shown to respond most strongly to water infrastructure development (Ritcher et al., 1996). We also use the most comprehensive and up-to-date database of dam development in the Mekong to determine when and where dams were built and how that could have affected water levels in the Mekong and Tonle Sap mainstreams. We hypothesized that although decadal and multiyear climatic variability is responsible for some of the observed wet season changes in past decades, there has been sufficient development throughout the basin since the 1990s to have caused observable hydrological alterations along the Mekong and Tonle Sap.

\section{Materials and methods}

Recorded daily water levels from 1960 to 2010 were obtained for monitoring stations in Chiang Saen, Luang Prabang, Vientiane, Mukdahan, Pakse, and Prek Kdam (Fig. 1 and Table 1) from the Mekong River Commission (MRC). These stations provide the longest and most accurate records of water levels in the Mekong. An extended series of records from
1910 to 2010 was obtained for the Stung Treng monitoring station in Cambodia. The data were quality checked by the MRC for consistency and accuracy (MRC, 2014). Changes in monitoring location throughout the study period were accounted for, resulting in a consistent and continuous water level data set (MRC, 2014). Parts of this same data set have been reported in multiple publications featuring climate change, sediment analyses, and water infrastructure development in the Mekong (e.g., Arias et al., 2012; Delgado et al., 2010, 2012; Lu and Siew, 2006; Räsänen and Kummu, 2012, Räsänen et al., 2013; Lu et al., 2014). Of particular importance was the correction of water level data for the Chiang Saen station, which underwent a change in location in 15 December 1993. Water level values subsequent to that date were corrected by $0.62 \mathrm{~m}$ in order to compare them with the water level before the date (Lu et al., 2014).

Hydropower reservoir volumes and dates of initial operation were gathered from MRC's hydropower database (MRC, 2014). This is an active database that was initially compiled in 2009 and the version used for this study was updated in 2013. This database has also been reported in recent publications (Xue et al., 2011; Kummu et al., 2010; Lauri et al., 2012; Piman et al., 2013b). Irrigation schemes and related reservoir information were obtained from MRC's Irrigation Database (MRC, 2014) and from information provided by the Royal Irrigation Department (Thailand), Electricity Generating Authority of Thailand (EGAT), and the Department of Energy Development and Promotion (DEDP) for the Chi-Mun River basin as complied by Floch and Molle (2007).

Daily water level records for each station were analyzed using the Indicators of Hydrologic Alternation (IHA) software (The Nature Conservancy, 2009), which permits the calculation of up to 32 statistical hydrological parameters and the level of alteration in post-development scenarios. A detailed analysis of all parameters is presented for Chiang Saen in order to compare our analysis with previous ones at this station (Lu and Siew, 2006; Lu et al., 2014). The analysis for the further downstream stations, however, focused on a selected set of parameters that have been demonstrated to be most related to hydropower operations in the Mekong (Kummu and Sarkkula, 2008; Lauri et al., 2012; Lu and Siew, 2006; Piman et al., 2013b; Lu et al., 2014; Wyatt and Baird, 2007), namely daily water level fluctuations, rise rates, fall rates, and 7-day minimum water levels (Fig. 1). To our knowledge, none of these four indicators have been significantly associated with other factors of hydrological alterations in the lower Mekong.

To analyze the effect of water resource development on temporal and spatial water levels in the Mekong River, the time series were divided into two periods and compared using a parametric analysis of deviation from means, deviations of the coefficient of variation, a range of variability approach (RVA; Ritcher et al., 1997), and analysis of variance (ANOVA). The division of the data sets had to represent a 
Table 1. Catchment areas and average historical seasonal flows (1960-2004) above each monitoring station. Source: MRC (2010) and verified with flow records.

\begin{tabular}{|c|c|c|c|c|}
\hline $\begin{array}{l}\text { Monitoring } \\
\text { station }\end{array}$ & $\begin{array}{r}\text { Catchment area } \\
\text { in } \mathrm{km}^{2}\end{array}$ & $\begin{array}{r}\text { Mean dry season } \\
\text { (Dec-May) flows } \\
\text { in } \mathrm{m}^{3} \mathrm{~s}^{-1}\end{array}$ & $\begin{array}{r}\text { Mean wet season } \\
\text { (Jun-Nov) flows } \\
\text { in } \mathrm{m}^{3} \mathrm{~s}^{-1}\end{array}$ & $\begin{array}{r}\text { Mean annual flows } \\
\text { in } \mathrm{m}^{3} \mathrm{~s}^{-1}\end{array}$ \\
\hline Chiang Saen (CS) & $189000(25 \%)$ & $1120(5 \%)$ & $4250(14 \%)$ & $2700(19 \%)$ \\
\hline Luang Prabang (LP) & $268000(35 \%)$ & $1520(6 \%)$ & $6330(21 \%)$ & $3900(27 \%)$ \\
\hline Vientiane (VT) & $299000(39 \%)$ & $1630(7 \%)$ & $7190(23 \%)$ & $4400(30 \%)$ \\
\hline Mukdahan (MH) & $391000(51 \%)$ & $2200(9 \%)$ & $12950(43 \%)$ & $7600(52 \%)$ \\
\hline Pakse (PS) & $545000(72 \%)$ & $2620(10 \%)$ & $16850(57 \%)$ & $9700(67 \%)$ \\
\hline Stung Treng (ST) & $635000(84 \%)$ & $3310(13 \%)$ & $22940(77 \%)$ & $13100(90 \%)$ \\
\hline Total basin & $760000(100 \%)$ & & & $14500(100 \%)$ \\
\hline
\end{tabular}

period of low water infrastructure development and a period of accelerated development in the basin. Furthermore, the division had to ensure that an adequate number of hydrological years were available for each period to enable statistical comparisons. Given these criteria, the data sets were divided into pre- and post-31 December 1990. A similar time frame has also been used by other researchers in defining the period where water infrastructure development in the Mekong gained significant importance initiated by the construction of the first dam in the Chinese cascade, Manwan (Lu and Siew, 2006; Räsänen et al., 2013; Lu et al., 2014).

\section{Results}

\subsection{Hydropower and irrigation development in the Mekong Basin}

The locations and commissioning period of hydropower dams in the Mekong Basin up to the end of 2010 is presented in Fig. 2, and a time series of the cumulative active storage at Pakse is presented in Fig. 3. Reservoir active storage, total storage, and the number of dams commissioned before 1991 and in 5-year intervals between 1991 and 2010 above each monitoring station are presented in Table 2. Total and active storage in the basin before the end of 1991 was 11609 and $7854 \mathrm{Mm}^{3}$ respectively, with a total of nine dams, three of which have active storage larger than $1000 \mathrm{Mm}^{3}$ (Table S1 in the Supplement). There were no dams in the mainstream of the Mekong prior to 1991. A significant increase in hydropower development in the upper Mekong Basin above Chiang Saen occurred after 1991, which can be quantified in terms of reservoir volume $\left(18216 \mathrm{Mm}^{3}\right)$ and active storage $\left(10773 \mathrm{Mm}^{3}\right)$ of the four dams developed along the mainstream in China. Between the end of 1991 and 2010 there was minimal development between Chiang Saen and Vientiane with only three small dams being built in tributaries (Table S1); however, a significant increase in development occurred in tributaries between Vientiane and Mukdahan, resulting in a near doubling of both active $\left(23117 \mathrm{Mm}^{3}\right)$ and

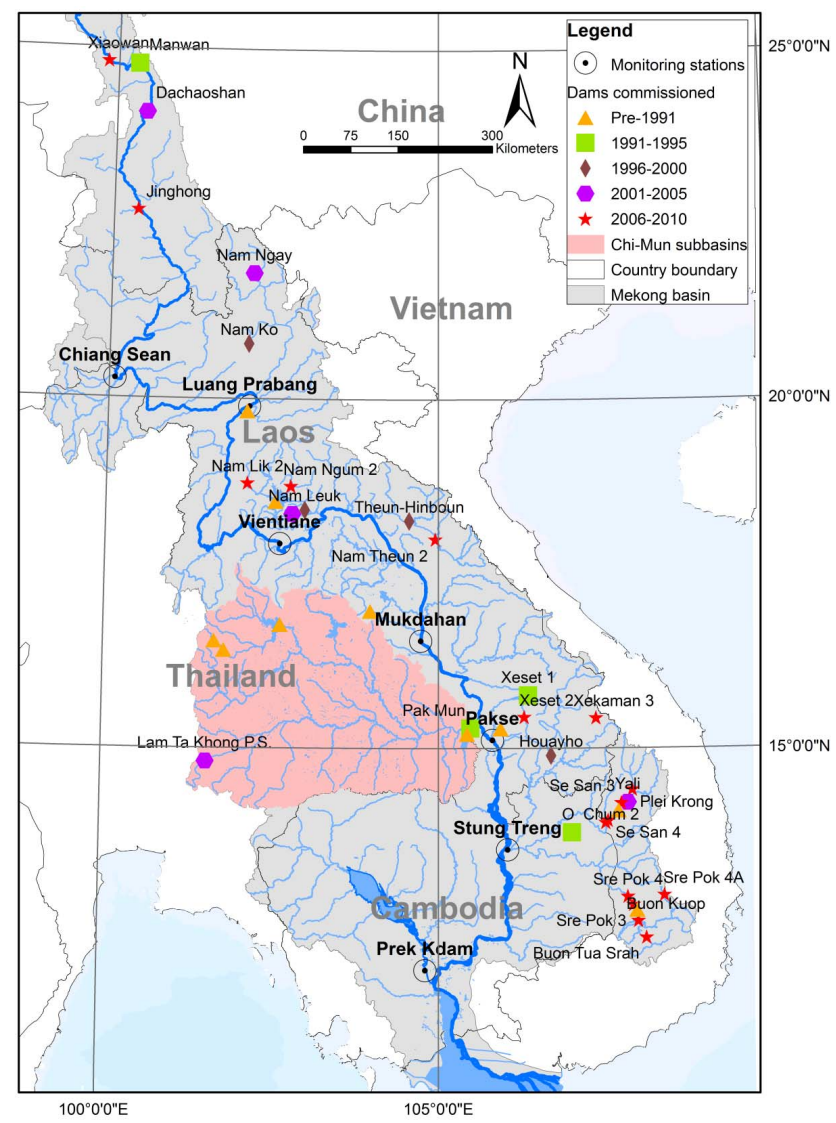

Figure 2. Operating dams and key hydrological monitoring stations in the Mekong Basin up to December 2010.

total storage $\left(37624 \mathrm{Mm}^{3}\right)$ above Mukdahan by 2010 . A number of tributary dams were also built between Mukdahan and Stung Treng, resulting in a total basin active storage of $29913 \mathrm{Mm}^{3}$ and total reservoir volume of $48700 \mathrm{Mm}^{3}$. After 1991, hydropower development in the upper tributaries of the Sesan, Srepok, and Sekong (3S) basin in Vietnam and Lao PDR accounted for an increase in $3374 \mathrm{Mm}^{3}$ of the total active storage. Seventeen out of the 39 dams in the 


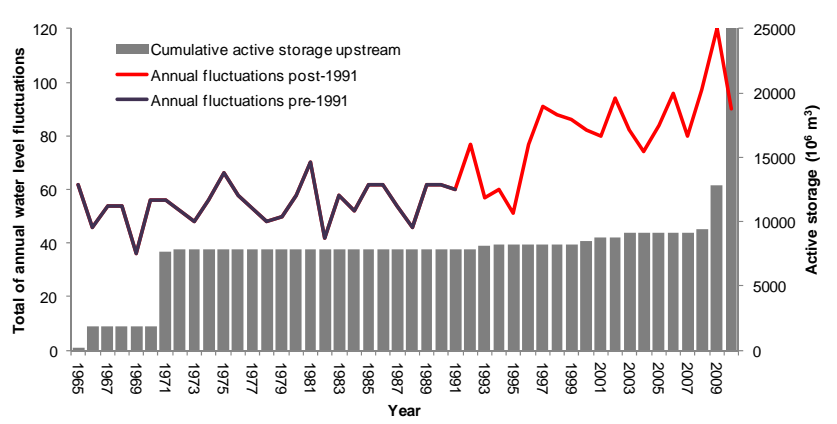

Figure 3. Temporal trend in water level fluctuations and cumulative active storage upstream of Pakse.

Mekong Basin became operational between 2006 and 2010, accounting for a $65 \%$ of the total active storage and $67 \%$ of the total reservoir volume in the Mekong Basin up to 2010.

The largest irrigation scheme in the Mekong Basin is located in the Chi-Mun basin in Thailand. The Chi-Mun basin is the largest tributary to the Mekong in terms of area, with the Mun and Chi River basins covering 67000 and $49477 \mathrm{~km}^{2}$, respectively. The combined Chi and Mun Rivers contribute an average annual flow of $32280 \mathrm{Mm}^{3}$ which discharges immediately above Pakse (MRC, 2005). These subbasins are highly developed, low-relief, with low runoff potential and significant reservoir storage for dry season irrigation, supporting a population of over 18 million people. The irrigated area is close to 1266000 ha with an annual water demand of $8963 \mathrm{Mm}^{3}$ and a foreseeable demand of over $12000 \mathrm{Mm}^{3}$ (Floch and Molle, 2007). The basins also include numerous flood prevention works, and most reservoirs are actually managed for joint irrigation, hydropower, and flood control. A summary of the largest multi-use reservoirs in the basin is provided in Table S2. The two largest reservoirs in the basin are Ubol Rattana $\left(2263 \mathrm{Mm}^{3}\right)$ and Sirindhorn (Lam Dom Noi; $1966 \mathrm{Mm}^{3}$ ) located in the upper watershed areas. However, the most influential reservoir in terms of controlling flows out of the basin is the Pak Mun dam. Although this reservoir is small $\left(225 \mathrm{Mm}^{3}\right)$, it was built in 1994 close to the outlet of the basin and controls the flow from $117000 \mathrm{~km}^{2}$ of drainage area. Further development of hydropower and reservoirs is highly unlikely in the basin, but construction of additional electricity generating plants in current multi-user reservoirs is possible (Floch and Molle, 2007).

\subsection{Parametric statistical analysis of hydrological alterations}

A parametric statistical analysis of multiple hydrological alteration indicators was done for each site. Detailed results of the analysis are first provided for the Chiang Saen site (Table 3), which is the main monitoring station below the four upper Mekong mainstream dams developed in China after
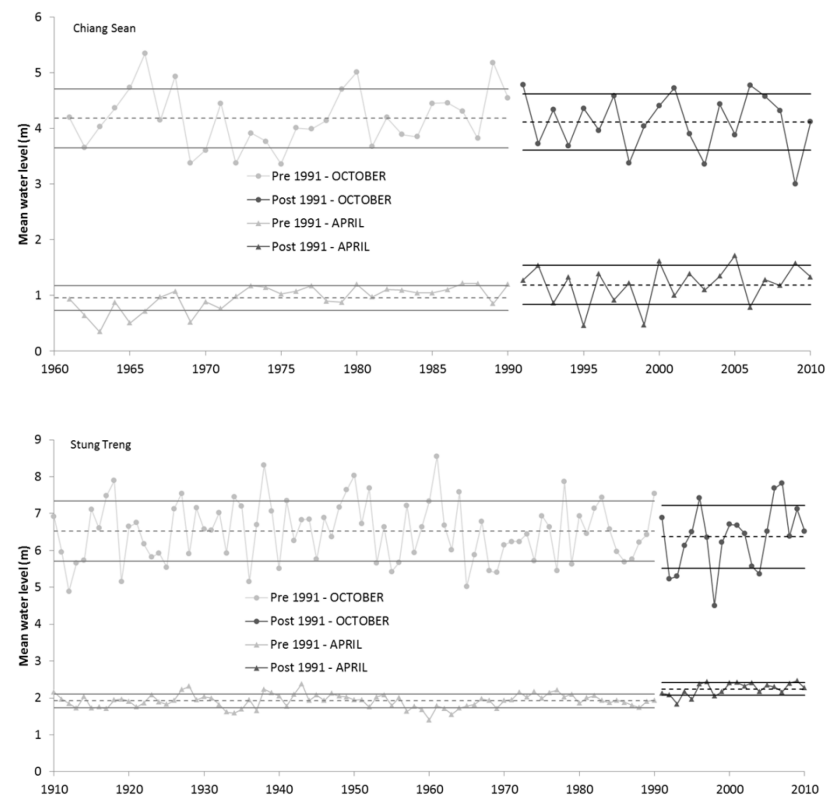

Figure 4. Mean measured water levels at Chiang Saen (1960-2010) and Stung Treng (1910-2010) for the months of April and October. Dashed lines indicate mean water levels for periods before and after 1991 and parallel solid lines indicate \pm 1 standard deviations around the mean for each period.

1991; thus, we assume there are a number of parameters with significant alterations at this station which are strongly linked to water infrastructure development, although some may be linked to climatic variability. Pre- and post-1991 mean monthly and extreme water levels, coefficients of variation, RVA low and high boundaries (representing 1 standard deviation from the mean), hydrological alteration factors (that is, the fraction of years in the post-development period in which a parameter falls out of a pre-development range of variability), and ANOVA significance levels ( $p \leq 0.001,0.01$, or 0.1 ) are shown for 32 hydrological alteration indicators. Results show moderate hydrological alteration factors $(>-0.33)$ and statistically significant $(p \leq 0.05)$ increases in water levels during the dry season months (February to May), the 30to 90-day minimum levels, low pulse counts, fall rates, and fluctuations. Analyses from other sites also show significant differences in rise rates. Given these findings, we focus our reporting on the analysis of multiple stations on seasonal water levels, 30-day minimum levels, rise rates, fall rates, and water level fluctuations.

\subsection{Seasonal changes in water levels}

An analysis of pre- and post-1991 water levels for Chiang Saen from 1960 to 2010 indicates that a significant increase $(p \leq 0.01)$ in mean water levels has occurred for the dry season month of April and a non-significant increase is observed for the wet season month of October (Fig. 4). A 
Table 2. Hydropower reservoir active and total storage $\left(\mathrm{Mm}^{3}\right)$ above monitoring stations in operation by 2010.

\begin{tabular}{|c|c|c|c|c|c|c|c|c|c|}
\hline \multirow{2}{*}{ Year } & \multicolumn{3}{|c|}{ Chiang Saen (CS) } & \multicolumn{3}{|c|}{ Luang Prabang (LP) } & \multicolumn{3}{|c|}{ Vientiane (VT) } \\
\hline & No. & Active & Total & No. & Active & Total & No. & Active & Total \\
\hline Pre-1991 & 0 & 0.00 & 0.00 & 0 & 0.00 & 0.00 & 1 & 0.02 & 0.03 \\
\hline $1991-1995$ & 1 & 257.00 & 920.00 & 2 & 257.00 & 920.01 & 2 & 257.00 & 920.01 \\
\hline 1996-2000 & 0 & 0.00 & 0.00 & 0 & 0.00 & 0.00 & 0 & 0.00 & 0.00 \\
\hline $2001-2005$ & 1 & 367.00 & 933.00 & 2 & 367.67 & 933.70 & 2 & 367.67 & 933.70 \\
\hline 2006-2010 & 2 & 10149.00 & 16363.00 & 2 & 10149.00 & 16363.00 & 2 & 10149.00 & 16363.00 \\
\hline Total & 4 & 10773.00 & 18216.00 & 6 & 10773.68 & 18216.71 & 7 & 10773.69 & 18216.73 \\
\hline \multirow{2}{*}{ Year } & \multicolumn{3}{|c|}{ Mukdahan (MH) } & \multicolumn{3}{|c|}{ Pakse (PS) } & \multicolumn{3}{|c|}{ Stung Treng (ST) } \\
\hline & No. & Active & Total & No. & Active & Total & No. & Active & Total \\
\hline Pre-1991 & 3 & 4856.82 & 7165.53 & 8 & 7852.12 & 11606.33 & 9 & 7853.62 & 11609.23 \\
\hline 1991-1995 & 2 & 257.00 & 920.01 & 4 & 382.30 & 1147.34 & 5 & 382.42 & 1147.49 \\
\hline 1996-2000 & 2 & 243.20 & 375.40 & 2 & 243.20 & 375.40 & 3 & 892.20 & 1049.50 \\
\hline 2001-2005 & 3 & 412.67 & 1038.43 & 4 & 702.67 & 1348.43 & 5 & 1481.69 & 2387.14 \\
\hline 2006-2010 & 5 & 17347.40 & 28124.99 & 6 & 17356.70 & 28134.86 & 17 & 19302.83 & 32476.44 \\
\hline Total & 15 & 23117.09 & 37624.35 & 24 & 26536.99 & 42612.35 & 39 & 29912.76 & 48669.79 \\
\hline
\end{tabular}

similaranalysis was conducted for the Stung Treng station in the lower Mekong using an extended data set between 1910 and 2010 (Fig. 4). Results indicate an increase of 2 standard deviations in the April (dry season) mean monthly water levels post-1991, but no significant alterations for the month of October (wet season).

A comparison of percent mean monthly alterations between pre- and post-1991 water levels for the Chiang Saen, Vientiane, Pakse, and Prek Kdam monitoring stations is presented in Fig. 5. Results indicate that mean water levels for Chiang Saen increased in excess of $30 \%$ for the dry season months of March and April, but monthly increases between June and December were mostly less than 5\%. Monthly mean water levels for Vientiane increased by $40 \%$ for the month of April, but alterations between June and December were lower than $10 \%$. For Pakse there was an increase of $30 \%$ in April, but relatively no alterations in the months from June to January. For the Prek Kdam water level station in the Tonle Sap, there was an observed mean water level increase of $10-20 \%$ for the months from November to May and a decrease in June and July of $\sim 10 \%$ or under. Changes in percent standard deviations were within the same magnitudes as observed changes in mean water levels for most data sets.

\subsection{Minimum water levels}

Thirty-day minimum water levels were used to characterize alterations to low water conditions. In general, greatest and most significant alterations were observed in the stations furthest upstream and downstream (Table 4). Changes to this parameter were modest but significant at Chiang
Saen $(+21 \%, p \leq 0.03)$, but became negligible at Luang Prabang and Mukdahan. Alterations became again significant at Stung Treng $(+12 \%, p \leq 0.001)$ and Prek Kdam $(+20 \%, p \leq 0.01)$.

\subsection{Water level rise and fall rate changes}

Water level variations were quantified by calculating the rise and fall rate. Rise rates are defined as the mean of all positive differences between consecutive daily water level values, and fall rates are the mean of all negative differences between consecutive daily water level values. Water level rise and fall rates $\left(\mathrm{m} \mathrm{day}^{-1}\right)$ for pre- and post-1991 for all stations are presented in Table 4. At the Chiang Saen, Luang Prabang, Vientiane, and Mukdahan monitoring stations, the mean differences between pre- and post-1991 rise rates were less than $\pm 10 \%$. The mean rise rate at Pakse changed by $-21 \%$ and then fell again to under $-8 \%$ at Stung Treng. The mean fall rate changes, however, ranged from over $42 \%$ at Chiang Saen to just over $5 \%$ in Pakse. At Stung Treng, mean fall rates increased by over $12 \%(p \leq 0.01)$. At Prek Kdam in the Tonle Sap, rise and fall rates changed significantly by approximately $-23 \%(p \leq 0.001)$ and $-11 \%(p \leq 0.01)$, respectively

\subsection{Number of water level fluctuations}

The difference in the number of water level changes (fluctuations) was calculated for each site. Water level fluctuations represent the number of times per year water levels have reversed from rising to falling or from falling to rising. Mean yearly values and coefficients of variations are reported 
Table 3. Indicators of hydrological alterations and alteration factors (within 1 standard deviation) at Chiang Saen.

\begin{tabular}{|c|c|c|c|c|c|c|c|c|}
\hline \multirow{3}{*}{$\begin{array}{l}\text { Indicators of } \\
\text { hydrological alterations }\end{array}$} & \multicolumn{4}{|c|}{ Pre-impact period: $1960-1990$} & \multicolumn{4}{|c|}{ Post-impact period: $1991-2010$} \\
\hline & \multicolumn{4}{|c|}{ RVA Boundaries ${ }^{\mathrm{a}}$} & \multirow[b]{2}{*}{ Means } & \multirow[b]{2}{*}{ Coeff of var. } & \multirow{2}{*}{$\begin{array}{r}\text { Hydrologic } \\
\text { alteration factor }^{b}\end{array}$} & \multirow{2}{*}{$\begin{array}{r}\text { ANOVA } \\
\text { signif. level }^{\mathrm{c}}\end{array}$} \\
\hline & Means & Coeff. of var. & Low & High & & & & \\
\hline \multicolumn{9}{|c|}{ Mean monthly values (m) } \\
\hline January & 1.396 & 0.206 & 1.108 & 1.683 & 1.52 & 0.1939 & 0.143 & \\
\hline February & 1.010 & 0.215 & 0.794 & 1.227 & 1.156 & 0.2401 & -0.143 & * \\
\hline March & 0.796 & 0.262 & 0.587 & 1.004 & 1.038 & 0.2551 & -0.333 & $* * *$ \\
\hline April & 0.954 & 0.237 & 0.728 & 1.180 & 1.188 & 0.2949 & -0.571 & ** \\
\hline May & 1.557 & 0.300 & 1.090 & 2.025 & 1.899 & 0.2329 & -0.114 & * \\
\hline June & 2.948 & 0.201 & 2.357 & 3.539 & 2.95 & 0.2358 & -0.152 & \\
\hline July & 4.639 & 0.168 & 3.860 & 5.417 & 4.918 & 0.1799 & 0.050 & \\
\hline August & 5.912 & 0.160 & 4.969 & 6.855 & 5.711 & 0.1716 & -0.182 & \\
\hline September & 5.262 & 0.158 & 4.430 & 6.094 & 5.301 & 0.1642 & -0.100 & \\
\hline October & 4.180 & 0.126 & 3.652 & 4.708 & 4.115 & 0.1228 & 0.000 & \\
\hline November & 3.023 & 0.163 & 2.530 & 3.515 & 2.975 & 0.2128 & -0.182 & \\
\hline December & 1.998 & 0.178 & 1.644 & 2.353 & 2.028 & 0.1628 & 0.000 & \\
\hline \multicolumn{9}{|c|}{ Extreme water conditions (m) } \\
\hline 1-day minimum & 0.623 & 0.315 & 0.427 & 0.819 & 0.599 & 0.546 & -0.357 & \\
\hline 3-day minimum & 0.631 & 0.313 & 0.434 & 0.829 & 0.649 & 0.532 & -0.357 & \\
\hline 7-day minimum & 0.650 & 0.304 & 0.452 & 0.847 & 0.728 & 0.424 & -0.550 & \\
\hline 30-day minimum & 0.734 & 0.274 & 0.533 & 0.935 & 0.886 & 0.312 & -0.325 & $*$ \\
\hline 90-day minimum & 0.895 & 0.230 & 0.689 & 1.102 & 1.097 & 0.220 & -0.325 & $* *$ \\
\hline 1-day maximum & 8.204 & 0.179 & 6.733 & 9.675 & 7.959 & 0.172 & -0.152 & \\
\hline 3-day maximum & 8.000 & 0.186 & 6.514 & 9.486 & 7.738 & 0.173 & -0.188 & \\
\hline 7-day maximum & 7.556 & 0.194 & 6.091 & 9.020 & 7.300 & 0.172 & -0.188 & \\
\hline 30-day maximum & 6.376 & 0.160 & 5.355 & 7.397 & 6.246 & 0.158 & -0.022 & \\
\hline 90-day maximum & 5.430 & 0.118 & 4.787 & 6.072 & 5.426 & 0.136 & -0.280 & \\
\hline \multicolumn{9}{|c|}{ Timing of extreme water conditions } \\
\hline Date of minimum & 87.2 & 0.039 & 72.8 & 101.5 & 91.5 & 0.064 & -0.152 & \\
\hline Date of maximum & 233.1 & 0.069 & 207.6 & 258.5 & 242.8 & 0.063 & -0.063 & \\
\hline \multicolumn{9}{|c|}{ Pulses frequency/duration (days) } \\
\hline Low pulse count & 2.3 & 0.595 & 0.9 & 3.7 & 3.5 & 0.755 & -0.5 & $* * *$ \\
\hline Low pulse duration & 26.5 & 0.863 & 10.4 & 49.3 & 6.4 & 0.691 & -0.7 & \\
\hline High pulse count & 5.3 & 0.407 & 3.2 & 7.5 & 5.4 & 0.280 & 0.3 & \\
\hline High pulse duration & 15.7 & 0.692 & 4.8 & 26.6 & 13.5 & 0.602 & 0.0 & \\
\hline \multicolumn{9}{|c|}{ Water condition changes } \\
\hline Rise rate $\left(\mathrm{m} \mathrm{day}^{-1}\right)$ & 0.186 & 0.155 & 0.157 & 0.214 & 0.189 & 0.157 & -0.071 & \\
\hline Fall rate $\left(\mathrm{m} \mathrm{day}^{-1}\right)$ & -0.102 & -0.128 & -0.115 & -0.089 & -0.145 & -0.202 & -0.850 & $* * *$ \\
\hline Number of fluctuations & 73.9 & 0.115 & 65.4 & 82.4 & 129.4 & 0.187 & -0.929 & $* * *$ \\
\hline
\end{tabular}

for pre- and post-1991 periods for each of the monitoring sites (Table 4). Results indicate a significant increase in the number of fluctuations for all stations along the Mekong in the post-1991 period. The percent increase in the mean number of yearly fluctuations in Chiang Saen is $75 \%$, but this value decreases steadily downstream to $17 \%$ at Mukdahan. An increase in the mean number of fluctuations was observed at Pakse with a mean increase of 26 fluctuations per year representing a $49 \%$ increase after 1991 . The percent increase in post-1991 fluctuations decreases in the downstream Stung Treng and Prek Kdam stations to 26 and $4 \%$, respectively.
Changes in the number of fluctuations per year between pre- and post-1991 for all stations are presented in Fig. 6. The number of fluctuations per year increase steadily after 1991 for all stations, but at different rates. An abrupt increase in yearly fluctuations after 1991 is evident between Mukdahan and Pakse, as well as a diminishing rate of post-1991 increases in fluctuations downstream from Chiang Saen to Mukdahan and from Pakse to Prek Kdam. 
Table 4. Hydrological alterations of selected indicators for pre- and post-1991 periods along the lower Mekong.

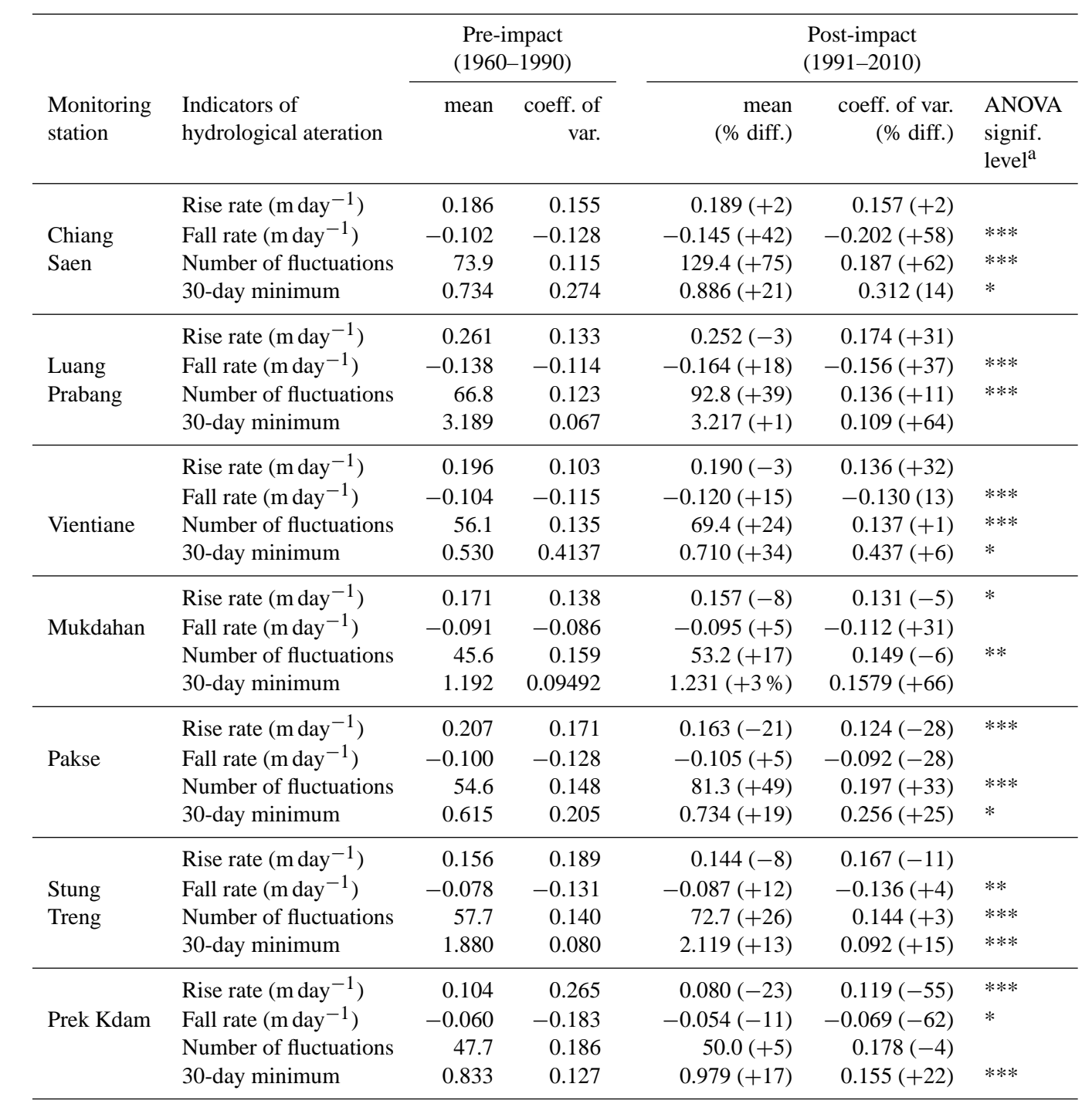

${ }^{a}$ Significance level codes: ***: $p \leq 0.001 ; * *: p \leq 0.01 ; *: p \leq 0.05$.

\section{Discussion}

Understanding and quantifying historical alterations influenced by water infrastructure development is important as a benchmark for monitoring and analyzing the impacts of future water infrastructure development in terms of ecological, economic, and social effects. Alterations to all reported hydrological parameters are important as they are indicators of wetland and river ecosystem habitat disruption, fish life histories, bank erosion, and sediment redistribution. Rise/fall water level rates and water level fluctuations influence drought stress on aquatic vegetation, entrapment of organisms on waterway islands or floodplains, and desiccation stress on low-mobility stream edge organisms (Poff et al., 1997). Above all, changes to these hydrological factors could have subsequent impacts on ecosystem productivity in the Tonle Sap (Arias et al., 2014a), the major driver of fish production and catches that are the largest source of protein consumed in the region (Hortle, 2007).

\subsection{Impacts of reservoir and irrigation operations on downstream water levels}

The hydrological alterations observed in the post-1991 period have a rational explanation within the context of water infrastructure development in the Mekong. The key hydrological alteration indicators (dry season, rise/fall rates, and fluctuations) quantified in the analysis of pre- and post-1991 water level monitoring data can be linked to temporal and spatial patterns of water resources development in the basin. 


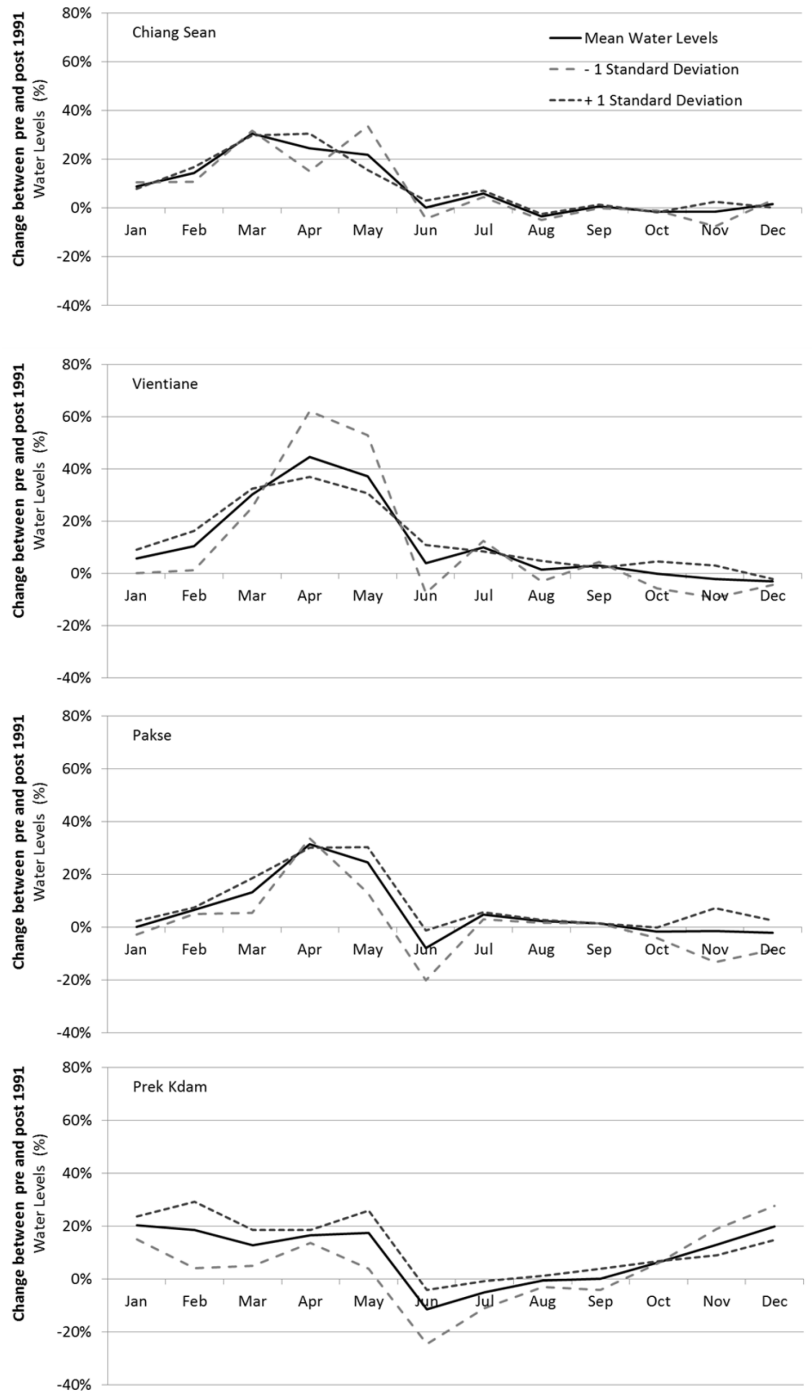

Figure 5. Change (\%) in average mean \pm 1 standard deviation for each month between pre- and post-1991 water levels for Chiang Saen, Vientiane, Pakse, and Prek Kdam.

\subsubsection{Dry season water levels}

To optimize electricity generation throughout the year, hydropower operations aim to fill reservoirs during the wet monsoon season and release water at higher volumes than natural flows in the dry season to extend the generation capacity. Operations of large reservoirs in the Mekong Basin were thus expected to increase downstream dry season water levels and marginally reduce wet season water levels (e.g., Lu et al., 2014). An analysis of historical rainfall patterns by Lu et al. (2014) upstream of Chiang Saen demonstrated that there has been little variation in precipitation patterns preand post-1991, although slight increases in temperature were noted. The development of the four mainstream hydropower dams in the upper Mekong in China is thus likely to have had a minor impact on the observed seasonal water level changes
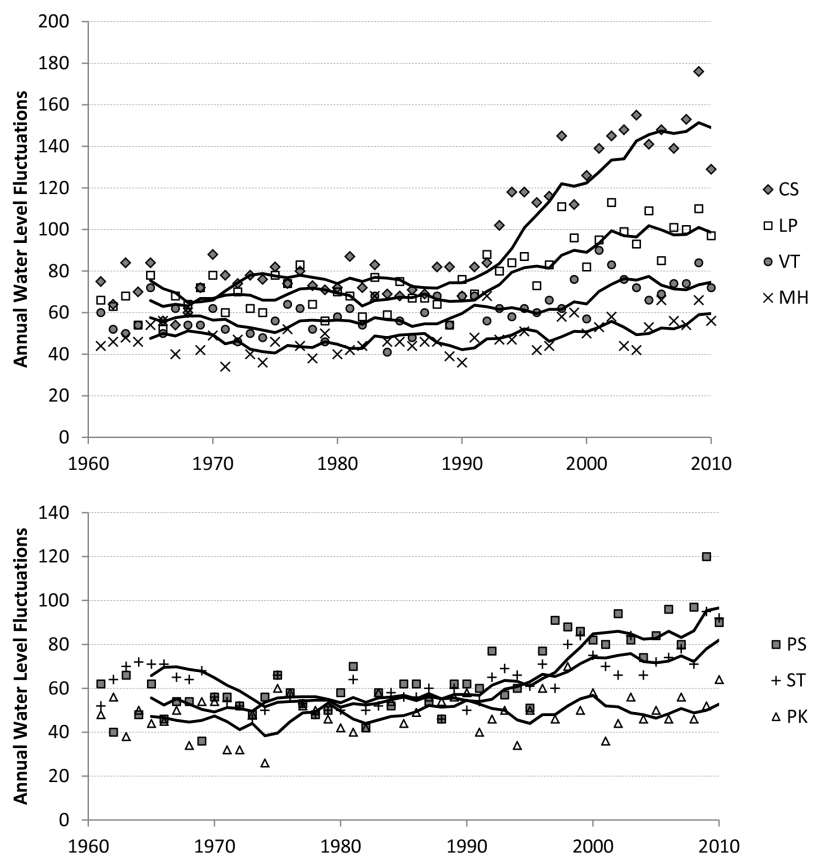

Figure 6. Number of annual water level fluctuations for each monitoring station between 1961 and 2010. Solid lines indicate a 5-year moving average for each station: Chiang Saen (CS), Luang Prabang (LP), Vientiane (VT), Mukdahan (MH), Pakse (PS), Stung Treng (ST), and Prek Kdam (PK).

since 1991, resulting in a modest increase in dry season water levels in the stations closer to the dams, but with diminishing effects further downstream. However, it has to be noted that the two largest dams were operational only after 2008 , and thus their mean effect on the pre- and post-1991 historical analysis of dry season water levels is relatively small, but it is expected to be observably larger in years to come. The difference between pre- and post-1991 30-day dry levels only becomes significant further downstream in Stung Treng and Prek Kdam, which can likely be attributed to development in the $3 \mathrm{~S}$ basin. Irrigation operations, on the other hand, would likely result in a reduction of downstream water levels or the rise rate during the dry season as water demand for agriculture increases (Floch and Molle, 2007).

\subsubsection{Water level rise and fall rates}

Irrigation will decrease downstream rise rates because water is abstracted during the growing season, preventing downstream river water levels from rising at their normal rates. Hydropower operations were not expected to increase downstream water level rise rates during normal operations; however, during reservoir flood control operations, rise rates would be reduced as water is held in reservoirs and slowly released thereafter. A significant change of $-21 \%$ water level rise rate was observed at Pakse post-1991, which can be attributed to the level of irrigation in the Chi-Mun basin during 
the growing (dry) season and flood control operations (wet and dry seasons) in the basin. A post-1991 near doubling of total reservoir storage in the upper tributaries between Vientiane and Mukdahan (Table 2) can also help explain an increase in rise rates downstream from Mukdahan due to increased irrigation operations and flood controls.

Retention of water in reservoirs during regular filling operations would increase water level fall rates downstream. Observed post-1991 high fall rates with minimal alterations in rise rates are indicative of hydropower reservoir filling and storage operations in the upper Mekong up to Vientiane. On the other hand, downstream water retention would decrease fall rates. For example, higher water levels in the Mekong River during the dry season will result in lower water level fall rates in the Tonle Sap as water is discharged more slowly into the Mekong.

\subsubsection{Water level fluctuations}

Arguably the most evident indicator of hydrological alteration related to hydropower reservoir operations is the number of downstream water level fluctuations (Wyatt and Baird, 2007). Even though this indicator is not a reflection of the volume of water being regulated, it is indeed indicative of the frequency and intensity of water regulation along a river. In a pristine large river, water level fluctuations are minimal and typically reflect seasonal changes; thus, an increase of this indicator in a large river is most likely a direct function of reservoir fill and release operations. Lu and Siew (2006) have already shown had this indicator increased at Chiang Saen once the Marwan dam was built. We have shown that this trend has continued to increase not only at Chiang Saen but also at stations further downstream.

We suggest that the post-1991 regulation of water in the Chi-Mun basin as a result of reservoir and irrigation schemes is a major cause of the large number of water level fluctuations observed at Pakse. The individual upstream dams in Chi-Mun may have limited impact on water levels at the outlet; however, irrigation operations during the growing (dry) season and the small $\left(225 \mathrm{Mm}^{3}\right)$ Pak Mun dam at the basin outlet, which controls hourly/daily flows to the greater Mekong, can directly alter downstream water level fluctuations. Although this sub-basin only contributes $5-10 \%$ of the total Mekong's discharge at Pakse (MRC, 2005), it is not the quantity of water over the year but rather the intensity and frequency of water management operations that is reflected in the large increase of water fluctuations at Pakse. In a similar manner, albeit at a lesser magnitude, the current regulation of waters in the $3 \mathrm{~S}$ may have contributed to water level fluctuations in Stung Treng. The impact of the $3 \mathrm{~S}$ tributary dams has been small up to 2010 because the dams are located in the highlands of these sub-basins (Piman et al., 2013b). The Chi-Mun basin, however, will not experience further significant hydropower development, whereas the $3 \mathrm{~S}$ basin has the potential for large reservoir storage projects in the near future (Piman et al., 2013b). Thus, we expect hydrological alterations (fluctuations, fall/rise rates, and seasonality) to increase beyond levels observed currently in Pakse and as far down as the Tonle Sap floodplain as has been predicted to some extent with numerical models (Arias et al., 2014b). Water infrastructure development for agriculture and hydropower is accelerating in other tributaries throughout Laos, and this could further impact water levels in Mukdahan and downstream in the near future. Furthermore, the development and operations of other dams in the mainstream of the lower Mekong, such as the Xayaburi dam in Laos, will undoubtedly have an immediate effect on rise/fall rates and fluctuations, potentially affecting critical fisheries and habitats in the lower Mekong.

\subsubsection{Impact on water levels of the Tonle Sap}

Because of the flow reversal phenomena in the Tonle Sap River, fall rates, rise rates, and fluctuations for the Prek Kdam station are affected both by Mekong River inflows/outflows and by contributing flows from the Tonle Sap catchment, which accounts for approximately $34 \%$ of yearly flows (Kummu et al., 2014). Alterations to rise and fall rates can affect the reversal of water flows in the Tonle Sap River. Of significant importance is that Prek Kdam exhibited a post-1991 decrease of 23 and $11 \%$ of rise and fall rates, respectively, and a decrease of 65 and $71 \%$ in the deviation of the coefficient of variation. The decrease in rise rates in the Tonle Sap River (Table 4) is likely a result of the increase in dry season water levels in the Mekong, resulting in a milder slope in the water level rise rate during the filling phase of the Tonle Sap. Rise and fall rates, as well as a significant decrease in the coefficient of variation for both parameters, indicates a modified flood pulse regime and more stable water levels in the Tonle Sap system as a result of upstream water infrastructure development. Most impact assessments of hydropower on the Tonle Sap have focused on seasonal water levels and spatial inundations patterns (see Kummu and Sarkkula, 2008; Arias et al., 2012, 2014a; Piman et al., 2013a), but alterations to the magnitude of fall/rise rates have been dismissed for the most part. Given the strong synchronicity between water flows, fish migrations, and fish catches in the Tonle Sap, it is probable that such hydrological alterations have had an undocumented effect on the fish ecology of this important ecosystem. To the extent of our knowledge, however, there are no reliable fish catch records or any ecological information pre-1991 that could be used to prove and quantify ecological shifts in past decades.

\subsection{Climate versus water infrastructure development}

The impacts of climate change are temporally complex and spatially varied and there is no consensus as to what the potential climate-driven water level alterations might be throughout the Mekong Basin despite multiple discussions 
on the subject (e.g., Kingston et al., 2011; Lauri et al., 2012; Thompson et al., 2013). Specific climate change factors, such as an increase in glacial melting, could theoretically contribute to increased water levels during the dry season as it has occurred in other large rivers with headwaters in the Himalayas (Xu et al., 2009); however, to date there is no consensus as to the extent alterations in Mekong flows might be associated with the Himalaya melting (Xu et al., 2009). Cook et al. (2012) found a significant relationship between Himalaya snow cover and dry season flows as far south as Kratie, but they concluded that contemporary and future changes in lower Mekong flows between March and May are negligible as a result of the conflicting effect of melting snow cover and increasing local precipitation. To our knowledge, there is no evidence of climate-induced alterations to indicators other than interannual and wet season extremes; besides, most of the previous studies highlighting the correlation between climate and river discharge patterns have only demonstrated contemporary alterations during the wet season months (Delgado et al., 2010; Räsänen and Kummu, 2013; Räsänen et al., 2013). The link between infrastructure development and water levels presented in this paper have largely excluded those indicators representing alterations during the wet season; thus, we argue that it is more likely that the increased number of water level fluctuations, as well as alterations to rise/fall rates observed in the post-1991 measurements at the various monitoring stations are evidence of the increasing impact of infrastructure development throughout the Mekong Basin. Furthermore, hydropower simulations in the $3 \mathrm{~S}$ basin demonstrate that changes to downstream water levels from various scenarios of climate change are minimal compared to the ability of hydropower operations to alter water levels (Piman et al., 2014).

\section{Conclusions}

This paper suggests that the perception of a pristine Mekong may have been outdated for over two decades. We have shown that hydropower operations and irrigation development in the Mekong may have already caused observable alterations to natural water levels along the Mekong mainstream and the Tonle Sap River beginning as early as 1991 . Increases in water levels during the dry season (March, April and May) of 35 to $20 \%$ post-1991 in Chiang Saen downstream to Stung Treng were documented, and such alterations, although relatively minor, are probably caused by water infrastructure development in the basin. The effect of the upper Mekong hydropower development tributary operations is clearly observable up to Mukdahan station in terms of water level fluctuations and fall rates. Alterations observed in Pakse and downstream are likely a result of irrigation development, flood control, and hourly/daily hydropower operations (at Pak Mun dam in particular) in the Chi-Mun basin.
Alterations observed downstream from Stung Treng will be exacerbated by the ongoing development in the $3 \mathrm{~S}$ basin. Previous studies have highlighted climate shifts occurring downstream from Pakse as the factor responsible for long-term hydrological alterations to wet season floods; however, alterations to dry season levels and water level rise/fall rates and fluctuations has not been related to climate variability, and as we have demonstrated in this paper, they were most likely caused by water infrastructure development in China and Thailand during the 1990s and 2000s.

Ongoing and proposed hydropower development will continue to increase the magnitude of water level alterations throughout the Mekong. Given the numerous water infrastructure development proposals which will significantly increase the basin's total active storage, drastic alterations to the hydrological pulse and subsequent ecological features in the Tonle Sap (Kummu and Sarkkula, 2008; Arias et al., 2012, 2014a) and the rest of the Mekong floodplains do not seem unrealistic. In particular, development in catchments such as the $3 \mathrm{~S}$ basin is currently occurring at a fast pace in a poorly coordinated fashion. Recent estimates with detailed modeling of the $3 \mathrm{~S}$ dams have shown considerably higher levels of alterations in the Tonle Sap than what has been observed or simulated before (Arias et al., 2014b), highlighting the potentially confounding impacts of these dams. Moreover, indicators of hydrological alterations in the Mekong highlighted in this paper, in particular rise rates, fall rates, and water level fluctuations, have been dismissed for the most part in modeling studies. Future research should explicitly simulate and analyze daily and even hourly water levels in order to capture these key indicators of change. Given the historical alterations we have documented and expected future development in the Mekong, research is also necessary on ecological indicators linked to the system's hydrology in order to quantify past, current, and future alterations before they become a threat to the integrity, biodiversity, and food security of the Mekong.

\section{The Supplement related to this article is available online at doi:10.5194/hess-11-4529-2014-supplement.}

Acknowledgements. The authors wish to thank the Mekong River Commission for providing the databases used in this paper. Funding was provided by the John D. and Catherine T. MacArthur Foundation through a project entitled "Critical Basin at Risk: Assessing and managing ecosystem pressures from development and climate change in the $3 \mathrm{~S}$ basin".

Edited by: P. van der Zaag 


\section{References}

Adamson, P. T., Rutherfurd, I. D., Peel, M. C., and Conlan, I. A.: The Hydrology of the Mekong River (Chapter 4), in: The Mekong, Biophysical Environment of an International River, edited by: Campbell, I., Academic Press, San Diego, 53-76, 2009.

Arias, M. E., Cochrane, T. A., Kummu, M., Killeen, T. J., Piman, T., and Caruso, B. S.: Quantifying changes in flooding and habitats in the Tonle Sap Lake (Cambodia) caused by water infrastructure development and climate change in the Mekong Basin, J. Environ. Manage., 112, 53-66, 2012.

Arias, M. E., Cochrane, T. A., Kummu, M., Lauri, H., Koponen, J., Holtgrieve, G. W., and Piman, T.: Impacts of hydropower and climate change on drivers of ecological productivity of Southeast Asia's most important wetland, Ecol. Modell., 272, 252-263, 2014a.

Arias, M. E., Piman, T., Lauri, H., Cochrane, T. A., and Kummu, M.: Dams on Mekong tributaries as significant contributors of hydrological alterations to the Tonle Sap Floodplain in Cambodia, Hydrol. Earth Syst. Sci. Discuss., 11, 2177-2209, doi:10.5194/hessd-11-2177-2014, 2014b.

Baran, E. and Myschowoda, C.: Dams and fisheries in the Mekong Basin, Aqua. Ecosyst. Health Manage., 12, 227-234, 2009.

Cook, B. I., Bell, A. R., Anchukaitis, K. J., and Buckley, B. M.: Snow cover and precipitation impacts on dry season streamflow in the Lower Mekong Basin, J. Geophys. Res., 117, D16116, doi:10.1029/2012JD017708, 2012.

Delgado, J. M., Apel, H., and Merz, B.: Flood trends and variability in the Mekong river, Hydrol. Earth Syst. Sci., 14, 407-418, doi:10.5194/hess-14-407-2010, 2010.

Delgado, J. M., Merz, B., and Apel, H.: A climate-flood link for the lower Mekong River, Hydrol. Earth Syst. Sci., 16, 1533-1541, doi:10.5194/hess-16-1533-2012, 2012.

Döll, P. and Zhang, J.: Impact of climate change on freshwater ecosystems: a global-scale analysis of ecologically relevant river flow alterations, Hydrol. Earth Syst. Sci., 14, 783-799, doi:10.5194/hess-14-783-2010, 2010.

Floch, P. and Molle, F.: Marshalling water resources: A chronology of irrigation development in the Chi-Mun River Basin Northeast Thailand, Colombo, Sri Lanka: CGIAR Challenge Program on Water and Food, 2007.

Gao, Y., Vogel, R. M., Kroll, C. N., Poff, N. L., and Olden, J. D.: Development of representative indicators of hydrologic alteration, J. Hydrol., 374, 136-147, doi:10.1016/j.jhydrol.2009.06.009, 2009

Grumbine, R. E. and Xu, J. C.: Mekong Hydropower Development, Science, 332, 178-179, 2011.

Hapuarachchi, H. A. P., Takeuchi, K., Zhou, M. C., Kiem, A. S., Georgievski, M., Magome, J., and Ishidaira, H.: Investigation of the Mekong River basin hydrology for 1980-2000 using the YHyM, Hydrol. Process., 22, 1246-1256, 2008.

Holtgrieve, G. W., Arias, M. E., Irvine, K. N., Ward, E. J., Kummu, M., Koponen, J., Richey, J. E., and Lamberts, D.: Ecosystem metabolism and support of freshwater capture fisheries in the Tonle Sap Lake, Cambodia, PLoS ONE, 8, e71395, doi:10.1371/journal.pone.0071395, 2013.

Hortle, K. G.: Consumption and the yield of fish and other aquatic animals from the Lower Mekong Basin, Mekong River Commission, Vientiane, Lao PDR, 2007.
Kingston, D. G., Thompson, J. R., and Kite, G.: Uncertainty in climate change projections of discharge for the Mekong River Basin, Hydrol. Earth Syst. Sci., 15, 1459-1471, doi:10.5194/hess-15-1459-2011, 2011.

Kummu, M. and Sarkkula, J.: Impact of the Mekong River flow alteration on the Tonle Sap flood pulse, Ambio, 37, 185-192, 2008.

Kummu, M., Lu, X. X., Wang, J. J., and Varis, O.: Basinwide sediment trapping efficiency of emerging reservoirs along the Mekong, Geomorphology, 119, 181-197, doi:10.1016/j.geomorph.2010.03.018, 2010.

Kummu, M., Tes, S., Yin, S., Adamson, P., Józsa, J., Koponen, J., Richey, J., and J. Sarkkula, J.: Water balance analysis for the Tonle Sap Lake-floodplain system, Hydrol. Process. 28, 1722-1733, doi:10.1002/hyp.9718, 2014.

Lauri, H., de Moel, H., Ward, P. J., Räsänen, T. A., Keskinen, M., and Kummu, M.: Future changes in Mekong River hydrology: impact of climate change and reservoir operation on discharge, Hydrol. Earth Syst. Sci., 16, 4603-4619, doi:10.5194/hess-164603-2012, 2012.

Li, S. J. and He, D. M.: Water level response to hydropower development in the upper Mekong River, Ambio, 37, 170-177, 2008.

Lehner, B., Liermann, C. R., Revenga, C., Vörösmarty, C., Fekete, B., Crouzet, P., Döll, P., Endejan, M., Frenken, K., Magome, J., Nilsson, C., Robertson, J. C., Rödel, R., Sindorf, N., and Wisser, D.: High-resolution mapping of the world's reservoirs and dams for sustainable river-flow management, Front. Ecol. Environ., 9, 494-502, doi:10.1890/100125, 2011.

Lu, X. X. and Siew, R. Y.: Water discharge and sediment flux changes over the past decades in the Lower Mekong River: possible impacts of the Chinese dams, Hydrol. Earth Syst. Sci., 10, 181-195, doi:10.5194/hess-10-181-2006, 2006.

Lu, X. X., Li, S., Kummu, M., Padawangi, R., and Wang, J. J.: Observed changes in the water flow at Chiang Saen in the lower Mekong: Impacts of Chinese dams?, Quatern. Int., 336, 145-157, doi:10.1016/j.quaint.2014.02.006, 2014.

MRC: Overview of the Hydrology of the Mekong River Basin, Mekong River Commission, Vientiane, p. 73, 2005.

MRC: State of the Basin Report 2010, Mekong River Commission, Vientiane, Lao PDR, 232 pp., 2010.

MRC: Mekong River Commission Data Information Services Master Catalogue, available at: http://portal.mrcmekong.org/ master-catalogue, last access: 21 February 2014.

Nilsson, C., Reidy, C. A., Dynesius, M., and Revenga, C.: Fragmentation and Flow Regulation of the World's Large River Systems, Science, 308, 405-408, doi:10.1126/science.1107887, 2005.

Piman, T., Lennaerts, T., and Southalack, P.: Assessment of hydrological changes in the lower Mekong basin from basinwide development scenarios, Hydrol. Process., 27, 2115-2125, doi:10.1002/hyp.9764, 2013a.

Piman, T., Cochrane, T. A., Arias, M. E., Green, A., and Dat, N. D.: Assessment of Flow Changes from Hydropower Development and Operations in Sekong, Sesan and Srepok Rivers of the Mekong Basin, J. Water Resour. Plann. Manage., 139, 723-732, doi:10.1061/(ASCE)WR.1943-5452.0000286, 2013b. 
Piman, T., Cochrane, T. A., Arias, M. E., Dat, N. D., and Vonnarart, O.: Managing Hydropower under Climate Change in the Mekong Tributaries, Chap. 11 in: Managing Water Resources under Climate Uncertainty: Examples from Asia, Europe, Latin America, and Australia, edited by: Shrestha, S., Anal, A. K., Salam, P. A., and van der Valk, M., Springer, in press, 2014.

Poff, N. L., Allan, J. D., Bain, M. B., Karr, J. R., Prestegaard, K. L., Richter, B. D., Sparks, R. E., and Stromberg, J. C.: The Natural Flow Regime, BioScience, 47, 769-784, doi:10.2307/1313099, 1997.

Poff, N. L., Olden, J. D., Merritt, D. M., and Pepin, D. M.: Homogenization of regional river dynamics by dams and global biodiversity implications, Proc. Natl. Acad. Sci., 104, 5732-5737, doi:10.1073/pnas.0609812104, 2007.

Räsänen, T. A. and Kummu, M.: Spatiotemporal influences of ENSO on precipitation and flood pulse in the Mekong River Basin, J. Hydrol., 476, 154-168, doi:10.1016/j.jhydrol.2012.10.028, 2013.

Räsänen, T. A., Lehr, C., Mellin, I., Ward, P. J., and Kummu, M.: Palaeoclimatological perspective on river basin hydrometeorology: case of the Mekong Basin, Hydrol. Earth Syst. Sci., 17, 2069-2081, doi:10.5194/hess-17-2069-2013, 2013.

Richter, B. D., Baumgartner, J. V., Powell, J., and Braun, D. P.: A Method for Assessing Hydrologic Alteration within Ecosystems, Conserv. Biol., 10, 1163-1174, doi:10.1046/j.15231739.1996.10041163.x, 1996.
Richter, B. D., Baumgartner, J., Wigington, R., and Braun, D.: How much water does a river need?, Freshw. Biol., 37, 231-249, doi:10.1046/j.1365-2427.1997.00153.x, 1997.

The Nature Conservancy: Indicators of Hydrologic Alternation Version 7.1, User's Manual, 2009.

Thompson, J. R., Green, A. J., Kingston, D. G., and Gosling, S. N.: Assessment of uncertainty in river flow projections for the Mekong River using multiple GCMs and hydrological models, J. Hydrol., 486, 1-30, doi:10.1016/j.jhydrol.2013.01.029, 2013.

WCD: Dams and development, A new framework for decisionmaking, The report of the World Commission on Dams, Earthscan Publications Ltd., London and Sterling, VA, USA, 404 pp. 2000.

Wyatt, A. B. and Baird, I. G.: Transboundary Impact Assessment in the Sesan River Basin: The Case of the Yali Falls Dam, Int. J. Water Resour. Develop., 23, 427-442, 2007.

Xu, J., Grumbine, R. E., Shrestha, A., Eriksson, M., Yang, X., Wang, Y., and Wilkes, A.: The Melting Himalayas: Cascading Effects of Climate Change on Water, Biodiversity, and Livelihoods, Conserv. Biol., 23, 520-530, doi:10.1111/j.15231739.2009.01237.x, 2009.

Xue, Z., Liu, J. P., and Ge, Q. A.: Changes in hydrology and sediment delivery of the Mekong River in the last 50 years: connection to damming, monsoon, and ENSO, Earth Surf. Process. Landf., 36, 296-308, 2011. 